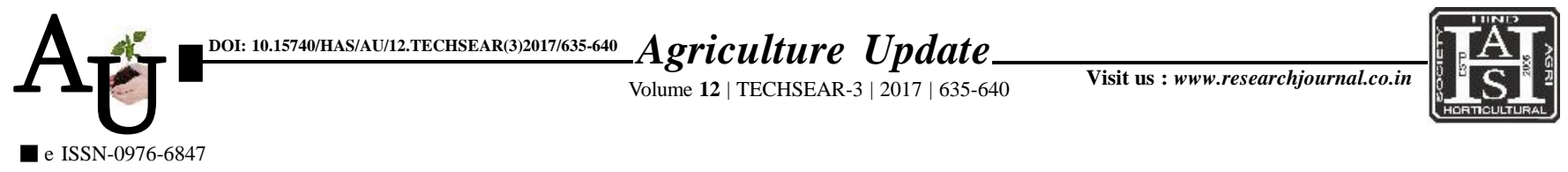

\title{
Research Article: Discriminant analysis for prediction and classification of farmers based on adoption of drought coping mechanisms
}

\section{G.R. HALAGUNDEGOWDA, ABHISHEK SINGH AND H.K. MEENAKSHI}

Article Chronicle: Received : 10.07.2017;

Accepted : 25.07.2017

KEY Words: Farmers, Coping mechanisms, Crop diversification
SUMMARY : The study was carried out to develop the classificatory statistical model to predict and classify the farmers into adopters and non-adopters in Kolar district of Karnataka for the year 2013. Linear discriminant analysiswas carried out by considering the various socio-economic characteristics of farmers as predictors and adoption behaviour of the farmers as response variable in order to assess the factors influencing on adoption of drought coping mechanisms. The result shows that the Box's M test is 161.3 with their F approximation 1.83 is non-significant (0.19) at 5\% level of significance, Eigen value (2.51) of the first function explains $100 \%$ of variations in the data which is potential enough to classifying the groups, wilk's lambda associated with the function $(\lambda=0.28)$ is transforms to a chi square of 140.82 with $12 \mathrm{DF}$, which is statistically significant and the following variables such asFarm Size (0.552), Extension Visits (0.574), Crop Diversification (0.321) and Crop Insurance (0.368) are relatively more important and positively influencing on discrimination of farmers group. Whereas the variable like Age (-0.516) negatively influencing on discrimination of adopters and non-adopters.

How to cite this article : Halagundegowda, G.R., Singh, Abhishek and Meenakshi, H.K. (2017). Discriminant analysis for prediction and classification of farmers based on adoption of drought coping mechanisms. Agric. Update, 12(TECHSEAR-3) : 635-640; DOI: 10.15740/HAS/AU/12.TECHSEAR(3)2017/635-640.
Author for correspondence:

$$
\text { G.R. }
$$

HALAGUNDEGOWDA

Section of Agricultural Statistics, Department of Farm Engineering, Institute of Agricultural Sciences, Banaras Hindu University, VARANASI (U.P.) INDIA

Email : hgowda8127@ gmail.com

See end of the article for authors' affiliations 